\title{
Are CBRT's Monetary Policy Statements Affected by ECB and FED Statements?
}

Necmettin Alpay Koçak ${ }^{*}$

\begin{abstract}
This paper aims to examine whether CBRT's monetary policy statements are affected by ECB and FED monetary policy statements. The sentiment analysis is performed to build the balance sentiment indicators (BSI) for CBRT, ECB, and FED from 2008 January to 2020 August using by their monetary policy statements. Individual and group properties of monthly BSI's are examined by unit root tests and the Bounds cointegration tests. The short and long-run effects of ECB and FED sentiments on CBRT's sentiments are investigated by ARDL and UECM models. The analysis is applied over the full sample period and two sub-samples which they represent the periods before and after 2013 May. That date is an important for Turkey in terms of the effects of the Fed stimulus program as well as relations with the IMF. The results imply that the CBRT, ECB, and FED's BSI's have statistically significant cointegration relationship over the full sample period and the period after 2013 June. Particularly after June 2013, the CBRT's statements are positively related with the ECB's and FED's statements in the long run however CBRT's statements are negatively affected by FED's statements in the short-run.
\end{abstract}

Keywords: Communication, Central bank, Monetary policy statements, Sentiment analysis, Cointegration.

JEL Classification: C32, C53, E31, E37.

\section{Öz - TCMB Para Politikası Açıklamaları ECB ve FED Açıklamalarından Etkileniyor mu?}

Bu makale, TCMB'nin para politikası açıklamalarının ECB ve FED para politikası açıklamalarından etkilenip etkilenmediğini incelemeyi amaçlamaktadır. 2008 Ocak - 2020 Ağustos döneminde TCMB, ECB ve FED için denge duyarlılık göstergelerini (BSI) para politikası tablolarından oluşturmak için duyarlılık analizi yapılmıştır. Aylık BSI'lerin bireysel ve grup özellikleri birim kök testleri ve Bounds eş bütünleşme testleri ile incelenir. ECB ve FED duygularının TCMB'nin duyguları üzerindeki kısa ve uzun vadeli etkileri ARDL ve UECM modelleri ile araştırılıyor. Analiz, tam örnekleme dönemi ve 2013 Haziran öncesi ve sonrasını temsil ettikleri iki alt örnek üzerinden uygulanmıştır. Bu tarih hem Fed teşvik programının etkileri hem de IMF ile ilişkiler açısından Türkiye için önemlidir. Bulgular, TCMB, ECB ve FED'in BSI'larının tüm örneklem dönemi ve 2013 Haziran sonrası dönemde istatistiksel olarak anlamlı eş bütünleşme ilişkisine sahip olduğunu göstermektedir. Özellikle Haziran 2013 sonrasında, Merkez Bankası açıklamaları uzun vadede ECB ve FED açıklamaları ile olumlu yönde ilişkiliyken, kısa vadede Merkez Bankası açıklamaları FED açıklamalarından olumsuz etkilenmiştir.

Anahtar Kelimeler: Illetişim, Merkez bankası, Para politikası beyanları, Duyarlıık analizi, Eşbütünleşme.

JEL Sınıflandırması: C32, C53, E31, E37.

\footnotetext{
* Hacettepe University, Faculty of Economic and Administrative Sciences, Department of Economics E-mail: alpaykocak@hacettepe.edu.tr - ORCID ID: https://orcid.org/0000-0002-4232-9985
}

DOI: 


\section{Introduction}

The communication strategy of a central bank has crucial importance to be understood its policy actions and assessments by the economic agents (Bernanke and Reinhart,2004). Especially, the monetary policy statements (hereafter statements) have a role of "forward guidance" to manage the economic agents expectations and to provide a transparent monetary policy (Hansen and McMahon,2016).

Communication policies of central banks are important in understanding their economic policies. Although it does not seem possible to establish a direct relationship between communication policies and economic policies, it is considered that determining the factors affecting communication may be beneficial in terms of predicting the statements of central banks by market agents. As a matter of fact, it is accepted that both ECB and FED meeting minutes are examined in detail by market players and future inferences are made.

Monetary policies committee statements, from which information about current or future can be derived, are also closely followed by the markets. Especially, they can gather information from the monetary policy committee statements about the optimism-monetary tightening and pessimism-monetary expansion situations of central banks.

This paper aims to explain the dynamics of the sentiments in the CBRT statements by using the sentiments in the ECB and the FED statements for the period between 2008 January and 2020 August. Individual and group properties of the sentiment indicators are examined by unit root tests and the Bounds testing approach suggested by Pesaran, Shin, and Smith (2001). The short and long-run dynamics of this relationship are investigated by the Autoregressive Distributed Lag (ARDL) and the Restricted Error Correction (RECM) models.

Especially, the financial relationship between Turkey and International Monetary Fund (IMF) can affect the central banks actions and decisions, hence statements. On the other hand, the announcement of FED about the roadmap to end of stimulus program may influence this relationship. All these events arised in May-2013. To show the effect of time on the among the central banks' sentiments, the analysis is performed on two sub-samples, before and after May-2013.

This paper is structured as follows. The related literature is reviewed and reported in the following section. The research model, the data and the methodology are described in the Section 3. The empirical findings are reported in the Section 4. Several implications and concluding remarks are given in the conclusion. 


\section{Literature Review}

In the literature, several studies have explored the statements' role in the communications strategy of central banks using sentiment analysis. Recently, Bholat (2015), Hansen, McMahon, and Prat (2018), and Stegmann (2019) analyzed the Federal Reserve (FED) statements while Berger, De Haan, and Sturm (2011) and Coenen et al. (2017) examined the European Central Bank (ECB) statements. Kahveci and Odabaş (2016) and Iglesias, Ortiz, and Rodrigo (2017) studied the Central Bank of the Republic of Turkey (CBRT) statements. The related studies are focused on time series properties of the statements' sentiment indicators, and a possible relationship between them and economic indicators.

There exists a consensus in the literature that the monetary policies of central banks are related to each other symmetrically or asymmetrically (Throop (1994), Siklos and Wohar (1997), Bec, Salem, and Collard (2002)). For instance, Bec, Salem, and Collard (2002) examines non-linear taylor-type monetary reaction functions for US, France and Germany. The authors suggest a model framework which allows one country's interest rate may have a role in other country's reaction function which data covers the years between 1982 and 1997. They use Generalized Method of Moments estimation method to estimate threshold models. The study concludes that the inter-related monetary reaction functions for the US, Germany and France can be represented by non-linear models.

Therefore, it can be argued whether there is a relationship among the communication strategies of central banks. There are very few studies which examines the relationship. Kahveci and Odabaş (2016) is the only study that visually analyzes the sentiments in ECB, CBRT and FED statements by comparing their behaviors over pre \& post-global economic crisis period. Recently, Armelius et al. (2020) suggest that there is a co-movement in the sentiments among the central banks. They analyzed the governor's speeches data set for 22 central banks, not including the CBRT. Therefore, it seems that there is a gap in the literature regarding the examination of the dynamic relationships among the CBRT, ECB and FED statements.

\section{Model, Data and Method}

A model can be suggested which includes CBRT statements as dependent variable and ECB and FED statements as independent variables. However, it would be wrong to assume that the CBRT's statements is only be affected by ECB and FED statements. Therefore, I also added the annual consumer inflation variable to the model. Annual consumer inflation variable may be related with CBRT's statements 
since the primary target of CBRT is to achieve price stability. Therefore, their actions and discourses may be shaped according to the annual consumer inflation.

According to Taylor-rule, central banks not only consider inflation but also consider output gap while deciding about monetary policy stance. However, the output gap variable is not included in this study, there are two reasons for this. The first is the sentiments in the MPC statements that are trying to be explained in this study, not the direct CBRT monetary policy stance. Second, it would cause the frequency of the data set used in the study to be aggregated, which could result in loss of information in the short-run analysis, since the output gap variable is compiled at quarterly basis.

On the other hand, this study attempts to test whether CBRT statements are affected by relatively exogenous ECB and FED statements. If a multivariate cointegration analysis were done between CBRT, ECB and FED, it would be thought that global conditions could be effective. Hence, I use the following model structure given in Eq. (1) to explain CBRT's sentiments.

$$
B S I_{C B R T, t}=\alpha_{0}+\alpha_{1} C P I_{T R, t}+\alpha_{2} B S I_{E C B, t}+\alpha_{3} B S I_{F E D, t}+\epsilon_{t}
$$

$C P I_{T R}$ is the annual consumer price inflation by months which covers the period between January 2008 and August 2020. CPI data is provided by TURKSTAT. BSI represents the balance sentiment indicators for CBRT, ECB and FED statements. I applied the sentiment analysis to the CBRT, ECB, and FED statements from 2008 January to 2020 August. I consider two types of sentiments, namely positivity and negativity, by following the method suggested by Rinker (2019). The analysis is performed to obtain positive and negative sentiments using the dictionaries defined in Hu and Liu (2004), Henry (2008), Loughran and McDonald (2011), Young and Soroka (2012), Mohammad and Turney (2013). The positivity (negativity) score is the ratio of the number of positive (negative) words to the total number of words in a statement. I assume the scores to show an exponential decay process running from the date of a speech until the next one. Afterward, I perform the aggregation by taking monthly averages on each score. The monthly score is calculated by the average of daily sentiments. Each $B S I$ is calculated by subtracting the negativity score from the positivity score for CBRT, ECB, and FED statements. Finally, I rescale the monthly BSI. The BSI indicator lies between 0 and 100 with 50 mean. If BS>50, the positivity is dominant on the statements, otherwise the negativity. If $B S=50$, the statements have a neutral sentiment. In summary, BSI is the balance value (balance between positive and negative) in the statements. An increase in the BSI indicator 
shows that there are more positive sentiments than negative ones in the statement, and vice versa. The data used in this paper is available at https://bit.ly/33mzXKd.

MPC statements are only taken into account in this study in order not to complicate the comparability and the method of the analysis. However, MPC statements are not the only tool by means of communication for central banks, and inflation reports, annual reports and other press releases are also seen as important tools. Another deficiency in the scope of the data is that the original language of the CBRT statements is not English, and there may be loss of meaning due to translation. Finally, the classification of sentiments as positive and negative and the exclusion of other forms of sentiment (e.g., emotions) can be seen as a limiting factor in evaluating the results of the analysis.

A time series is considered as stationary in which level the mean and variance of the time series do not change depending on time and the relationship between the two periods depends only on the distance (Gujarati,2009). Identification of stationary level is important to selection of the methods for further empirical analysis. Five different tests, which are frequently used in the literature, are used in this paper. These are Augmented Dickey-Fuller (hereafter ADF) (Dickey and Fuller, 1981), Philips-Perron (hereafter PP) (Phillips and Perron,1988), Elliott, Rothenberg and Stock (hereafter ERS) (Elliott, Rothenberg, and Stock,1996), Kwiatkowski et al. (hereafter KPSS) (Kwiatkowski et al.,1992), and Zivot-Andrews (hereafter ZA) (Zivot and Andrews, 1992) tests. The ADF performs a test which the series is not stationary in the null hypothesis. The PP also performs a test which the series is not stationary in the null hypothesis. The possible autocorrelation problem in the test equation is solved by determining the appropriate lag length in the ADF test, while the autocorrelation and variance problem in the test equation is solved with a non-parametric approach (HAC) in the PP test. On the other hand, the most important disadvantage of the PP test is that it is based on asymptotic theory and the suggested HAC correction is invalid in short time series. ADF and PP tests are sensitive to structural breaks and have poor test strengths in small samples. In the ERS test, the ADF test equation is used, but it clears the series from the linear trend as "local". Thus, the ERS test is superior to the ADF test in terms of test strength. Unlike other tests, the KPSS test tests that the series is stationary in the null hypothesis, and in this way it is a more advanced version of the ADF test in terms of test power. The ZA test is a stronger stationary test compared to other tests in terms of sensitivity to structural breaks. In this test, a single structural break is allowed in the series and the minimum observation of the t-statistics in the ADF test is the observation that the break is experienced. Zivot-An- 
drews test is the same as ADF, PP and ERS in terms of hypothesis structure. The optimal lag lengths for the test equations are selected according to the AIC (Akaike Information Criterion) criterion.

According to the studies of Engle and Granger (1987), Johansen (1988) and Johansen and Juselius (1990), the cointegration analyses can be applied as long as there are at least two I(1) series. The cointegration relationship with these tests cannot be investigated if one or more series are $\mathrm{I}(\mathrm{O})$. The Bounds test approach suggested by Pesaran, Shin, and Smith (2001) eliminates this problem. The Bounds test is applied regardless of whether the variables used in the model are I(0) or I(1) and the null hypothesis is there is no cointegration relationship among the variables. To do this, a preliminary $\operatorname{ARDL}$ model with the orders $\operatorname{ARDL}\left(p, q_{1}, q_{2}, q_{3}\right)$ is estimated to determine the optimal orders, then UECM are estimated with the orders minus one, i.e. $\left(p-1, q_{1}-1, q_{2}-1, q_{3}-1\right)$. The adaptation of UECM to this paper is as given in Eq. (2):

$$
\begin{aligned}
\triangle B S I_{C B R T, t}= & v+\phi_{1} B S I_{C B R T, t-1}+\phi_{2} C P I_{T R, t-1}+\phi_{3} B S I_{E C B, t-1}+\phi_{4} B S I_{F E D, t-1} \\
& +\sum_{i=1}^{p-1} \beta_{i} \Delta B S I_{C B R T, t-i}+\sum_{j=0}^{q_{1}-1} \gamma_{j} \Delta C P I_{T R, t-j} \\
& +\sum_{k=0}^{q_{2}-1} \rho_{k} \Delta B S I_{E C B, t-k}+\sum_{l=0}^{q_{3}-1} \pi_{l} \Delta B S I_{F E D, t-l} \\
& +\xi_{t} ; \quad t=\operatorname{Jan} 2008, \ldots, \operatorname{Aug} 2020
\end{aligned}
$$

The optimal values for the orders $\left(p, q_{1}, q_{2}, q_{3}\right)$ are selected according to the Adjusted $R^{2}$ criterion up to maximum orders equal to 3 for each. The absence of auto-correlation problem also taken into cosideration in the selection of lag length selection procedure. Long-run properties of the Eq. (2) are investigated by the Wald bounds-test for no cointegration proposed by Pesaran, Shin, and Smith (2001). According to Pesaran, Shin, and Smith (2001), the long-run relationship distinguishes among 5 different cases. These differ in terms of whether the 'intercept' and/or the 'trend' are restricted to participate in the long-run relationship, or they are unrestricted and so they participate in the short-run relationship. In this paper, I use the Case 3 which the cointegration model contains unrestricted intercept and no trend. The bounds test is a Wald test on the parameters of Eq. (2) expressed as an F-statistic. Since the distribution of the $F$ test statistics used is not standard in the test, Pesaran, Shin, and Smith (2001) suggests to use the upper and lower critical value bounds in a certain significant level. A Wald test is applied on the parameters 
of Eq. (2) for the following hypotheses given in Eq. (3):

$$
\begin{array}{r}
\mathbf{H}_{0}: \phi_{1}=\phi_{2}=\phi_{3}=\phi_{4}=0 \\
\mathbf{H}_{\mathbf{1}}: \text { Not } H_{O}
\end{array}
$$

If the calculated $\mathrm{F}$ statistic is less than the Pesaran lower critical value, there is no cointegration relationship between the series. If the calculated $\mathrm{F}$ statistic is between the lower and upper critical value, a definite interpretation cannot be made and other cointegration test approaches should be applied. If the calculated F statistic is above the upper critical value, there is a cointegration relationship between the series.

Pesaran, Shin, and Smith (2001) suggests the t-bounds test for no cointegration. It is a t-test on the parameters of Eq. (2). The t-bounds test can be applied for cases 1,3 and 5. Pesaran, Shin, and Smith (2001) also suggests to use the upper and lower critical value bounds for t-test in a certain significant level. A t-test is applied on the parameter of Eq. (2) for the following hypotheses given in Eq. (4). The evaluation approach described above for the F-test is equally valid for the t-test.

$$
\begin{aligned}
& \mathbf{H}_{\mathbf{0}}: \phi_{1}=0 \\
& \mathbf{H}_{\mathbf{1}}: \phi_{1} \neq 0
\end{aligned}
$$

The long-run is a theoretical concept in which the relationship defined by model is in equilibrium and all variables have fully adjusted and are in equilibrium. In contrast, the short-run defines the situation where some discrepancies can be seen due to some constraints, and the model is not fully in equilibrium.

ARDL model is used to measure the long-run effects of the $B S I_{E C B}$ and the $B S I_{F E D}$ on the $B S I_{C B R T}$ after the cointegration relationship between $B S I$ indicators has been determined. The ARDL model with the orders $\left(p, q_{1}, q_{2}, q_{3}\right)$ specification is given in Eq. (5):

$$
\begin{aligned}
B S I_{C B R T, t}= & c_{0}+\sum_{i=1}^{p} \delta_{1, i} B S I_{C B R T, t-i}+\sum_{j=0}^{q_{1}} \delta_{2, j} C P I_{T R, t-j} \\
& +\sum_{k=0}^{q_{2}} \delta_{3, k} B S I_{E C B, t-k}+\sum_{l=0}^{q_{s}} \delta_{4, l} B S I_{F E D, t-l} \\
& +\epsilon_{t} ; \quad t=\text { Jan } 2008, \ldots, \text { Aug } 2020
\end{aligned}
$$

The estimates of the coefficients in Eq. (5) are robust under the assumption of lack of auto-correlation, heteroskedasticity, non-linearity and structural change in $\hat{\epsilon}_{t}$ 
. The fitted residuals are tested by the $B G(p)$ test (Breusch,1978) against auto-correlation for $p$ order, the GQ test (Goldfeld and Quandt,1965) against heteroskedasticity, the HC test (Harvey and Collier, 1977) against non-linearity and the M-test (Zeileis,2006) against structural change.

Eq. (6) explains how to obtain the long-run coefficients which are calculated from Eq. (5) following the method suggested by Bårdsen (1989). The delta method is used for approximating the standard errors (and thus the t-statistics) of the estimated coefficients.

$$
\begin{array}{r}
\mu=\frac{c_{0}}{1-\sum_{i=1}^{p}} \\
\alpha_{j}=\frac{\sum_{l=0}^{q_{j}} \delta_{j, l}}{1-\sum_{i=1}^{p} \delta_{1, i}} \quad \forall j=C P I_{T R}, B S I_{E C B}, B S I_{F E D}
\end{array}
$$

$\mu$ is the constant term in the long-run relationship, $\alpha$ is the long-run coefficients of the variables in question.

By Eq. (7), the RECM has been established as follows to investigate the relationship between variables in the short-run.

$$
\begin{aligned}
\triangle B S I_{C B R T, t}= & v+\sigma_{1} E C T_{t-1}+\sum_{i=1}^{p-1} \beta_{i} \Delta B S I_{C B R T, t-i}+\sum_{j=0}^{q_{1}-1} \gamma_{j} \Delta C P I_{T R, t-j} \\
& +\sum_{k=0}^{q_{2}-1} \rho_{k} \Delta B S I_{E C B, t-k}+\sum_{l=0}^{q_{3}-1} \pi_{l} \Delta B S I_{F E D, t-l} \\
& +\xi_{t} ; \quad t=\operatorname{Jan} 2008, \ldots, \text { Aug } 2020
\end{aligned}
$$

The $E C T_{t-1}$ is the lagged value of $\hat{\epsilon}_{t}$ derived from the Eq. (5). $\sigma_{1}$ indicates how much of the imbalance in the short-run will be corrected in the long-run. The estimates of the coefficients in Eq. (7) are robust under the assumption of lack of auto-correlation, heteroskedasticity, non-linearity and structural change in $\hat{\xi}_{t}$. Same diagnostic tests applied to Eq. (5) are also applied to the $\hat{\xi}_{t}$.

As mentioned before, the analysis period covers the date between January 2008 and August 2020. I called this coverage as "Full sample". On the other hand, the 
relationship between the $B S I_{C B R T}$, the $B S I_{E C B}$ and the $B S I_{F E D}$ can vary by time. Especially, the financial relationship between Turkey and International Monetary Fund (IMF) can affect the central banks actions and decisions, hence statements. On the other hand, the announcement of FED about the roadmap to end of stimulus program may influence this relationship. To show the effect of time on this relationship, I divide the sample into two sub-samples. The first sample covers the period from January 2008 and May 2013. The date of May 2013 is the important since it is the date when the financial relationship between Turkey and IMF officially ended and FED announced a roadmap to end stimulus program. The second sample covers the period after June 2013 until August 2020. In the study, dummy variable is not defined to show any change of relationship in May 2013, because the definition of the dummy and/or the interaction variables should have been applied under the fix lag length in the model. However, it is preferred in this study to divide the sample into two parts rather than assuming fixed numbers of lags. Therefore, the cointegration and long/short-run analysis are performed to full and two sub-samples.

\section{Empirical Results}

The descriptive statistics for BSI indicators of CBRT, ECB, and FED are reported in Table 1. The $B S I_{F E D}$ implies positivity, $B S I_{E C B}$ implies neutrality and $B S I_{C B R T}$ $B S I_{C B R T}$ implies negativity on average. The $B S I_{C B R T}$ has the highest standard deviation which means it shows big fluctuations around the mean. Beside, $C P I_{T R}$ has $3.99 \%$ and $25.24 \%$ values of minimum and maximum, respectively.

Table 1. Descriptive statistics

\begin{tabular}{lrrrr}
\hline Statistics & $\mathrm{BSI}_{\mathrm{CBRT}}$ & $\mathrm{BSI}_{\mathrm{ECB}}$ & $\mathrm{BSI}_{\mathrm{FED}}$ & $\mathrm{CPI}_{\mathrm{TR}}$ \\
\hline N.obs. & 152 & 152 & 152 & 152 \\
Mean & 41.54 & 50.21 & 56.83 & 9.73 \\
Std.Dev. & 10.67 & 4.19 & 7.12 & 3.78 \\
Max. & 67.13 & 61.32 & 78.23 & 25.24 \\
Min. & 9.23 & 36.91 & 36.31 & 3.99 \\
\hline
\end{tabular}

$B S I_{C B R T}, B S I_{E C B}$, and $B S I_{F E D}$ as well as $C P I_{T R}$ are presented in Figure 1. It is seen that the $B S I_{E C B}$ show stable at the neutrality level after the year 2013. By contrast, it can be claimed that $B S_{F E D}$ shows upward trend clearly after the election Donald Trump as president in 2016. Even though $B S_{C B R T}$ shows fluctuations by time, it is seen that it moves around a stable mean which is lower than neutrality after 2012. 
Figure 1. Balance sentiment indicators of CBRT, ECB, FED and Turkish consumer price inflation
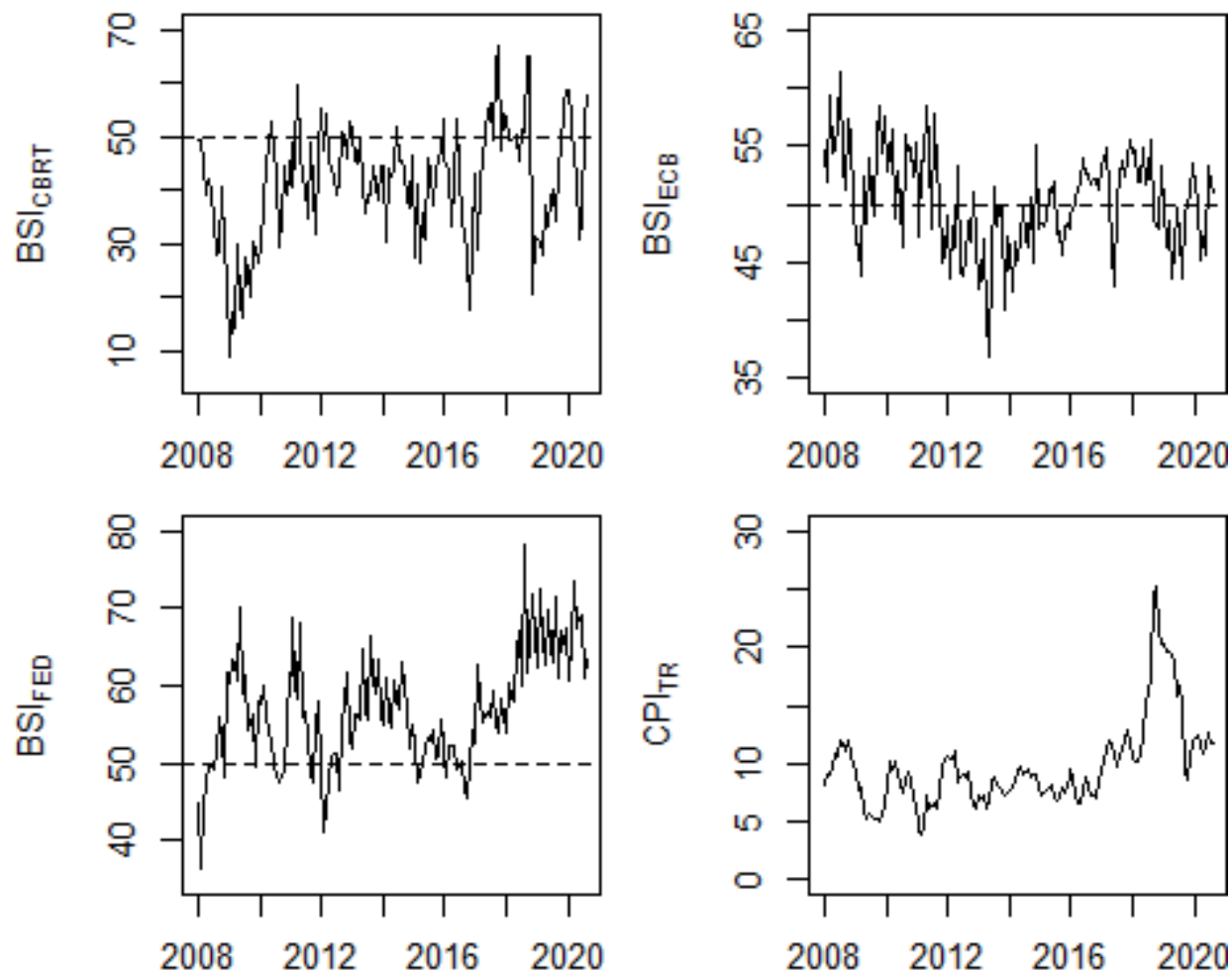

Table 2 shows the results of five different unit root tests for $B S I$ and $C P I_{T R}$ variables. The first column represents the name of the series. The second column provides the null and alterative hypothesis of the tests in terms of integration order. While I(0) expression expresses stationarity in its level, I(1) expresses stationarity at first differences. The fourth column provides the information about model specification of the test. From Table 2, it may be claimed that $B S_{C B R T, t}$ and $B S_{E C B, t}$ are stationary at the I(0) order, however the $B S_{F E D, t}$ and $C P I_{T R, t}$ series are stationary at $\mathrm{I}(1)$ order. 
Table 2. Unit root test results

\begin{tabular}{|c|c|c|c|c|c|c|}
\hline Series & $\begin{array}{l}\text { Null } \\
\text { vs. Alternative } \\
\text { Hypothesis }\end{array}$ & Test name & Test type & $\begin{array}{r}\text { Lag } \\
\text { length }\end{array}$ & $\begin{array}{r}\text { Test } \\
\text { Statistics }\end{array}$ & Critical Values \\
\hline$B S I_{C B R T, t}$ & $\mathrm{I}(1)$ vs I(0) & ADF & drift & 1 & $-4.3097^{* * *}$ & $-3.46 ;-2.88 ;-2.57$ \\
\hline$B S I_{C B R T, t}$ & $\mathrm{I}(1)$ vs I(0) & PP & with intercept & 13 & $-5.7387^{* * *}$ & $-3.47 ;-2.88 ;-2.58$ \\
\hline$B S I_{C B R T, t}$ & $\mathrm{I}(1)$ vs I(0) & ERS & with intercept & 12 & $-2.7262^{* * *}$ & $-2.58 ;-1.94 ;-1.62$ \\
\hline$B S I_{C B R T, t}$ & $\mathrm{I}(0)$ vs I(1) & KPSS & $\mathrm{mu}$ & 13 & 0.3451 & $0.74 ; 0.46 ; 0.35$ \\
\hline$B S I_{C B R T, t}$ & $\mathrm{I}(1)$ vs I(0) & ZA & intercept & 12 & -4.3899 & $-5.34 ;-4.8 ;-4.58$ \\
\hline$B S I_{C B R T, t}$ & $\mathrm{I}(2)$ vs I(1) & $\mathrm{ADF}$ & drift & 1 & $-11.8947^{* * *}$ & $-3.46 ;-2.88 ;-2.57$ \\
\hline$B S I_{C B R T, t}$ & $\mathrm{I}(2)$ vs I(1) & PP & with intercept & 13 & $-19.3705^{* * *}$ & $-3.47 ;-2.88 ;-2.58$ \\
\hline$B S I_{C B R T, t}$ & $\mathrm{I}(2)$ vs I(1) & ERS & with intercept & 11 & $-4.7458^{* * *}$ & $-2.58 ;-1.94 ;-1.62$ \\
\hline$B S I_{C B R T, t}$ & $\mathrm{I}(1)$ vs I(2) & KPSS & $\mathrm{mu}$ & 13 & 0.0864 & $0.74 ; 0.46 ; 0.35$ \\
\hline$B S I_{C B R T, t}$ & $\mathrm{I}(2)$ vs I(1) & ZA & intercept & 12 & $-4.7285^{* *}$ & $-5.34 ;-4.8 ;-4.58$ \\
\hline$B S I_{E C B, t}$ & $I(1)$ vs $I(0)$ & ADF & drift & 1 & $-4.8314^{* * \star}$ & $-3.46 ;-2.88 ;-2.57$ \\
\hline$B S I_{E C B, t}$ & $\mathrm{I}(1)$ vs I(0) & $\mathrm{PP}$ & with intercept & 13 & $-7.6225^{* * *}$ & $-3.47 ;-2.88 ;-2.58$ \\
\hline$B S I_{E C B, t}$ & $I(1)$ vs I(0) & ERS & with intercept & 12 & -1.1014 & $-2.58 ;-1.94 ;-1.62$ \\
\hline$B S I_{E C B, t}$ & $\mathrm{I}(0)$ vs I(1) & KPSS & $\mathrm{mu}$ & 13 & 0.2447 & $0.74 ; 0.46 ; 0.35$ \\
\hline$B S I_{E C B, t}$ & $\mathrm{I}(1)$ vs I(0) & ZA & intercept & 12 & -3.8197 & $-5.34 ;-4.8 ;-4.58$ \\
\hline$B S I_{E C B, t}$ & $\mathrm{I}(2)$ vs I(1) & $A D F$ & drift & 1 & $-12.9712^{* * *}$ & $-3.46 ;-2.88 ;-2.57$ \\
\hline$B S I_{E C B, t}$ & $\mathrm{I}(2)$ vs I(1) & PP & with intercept & 13 & $-28.8055^{* * *}$ & $-3.47 ;-2.88 ;-2.58$ \\
\hline$B S I_{E C B, t}$ & $I(2)$ vs I(1) & ERS & with intercept & 11 & -0.5501 & $-2.58 ;-1.94 ;-1.62$ \\
\hline$B S I_{E C B, t}$ & $\mathrm{I}(1)$ vs I(2) & KPSS & $\mathrm{mu}$ & 13 & 0.0766 & $0.74 ; 0.46 ; 0.35$ \\
\hline$B S I_{E C B, t}$ & $\mathrm{I}(2)$ vs I(1) & ZA & intercept & 12 & $-5.3801^{* * \star}$ & $-5.34 ;-4.8 ;-4.58$ \\
\hline$B S I_{F E D, t}$ & $\mathrm{I}(1)$ vs I(0) & ADF & drift & 1 & $-3.9107^{\star \star \star}$ & $-3.46 ;-2.88 ;-2.57$ \\
\hline$B S I_{F E D, t}$ & $\mathrm{I}(1)$ vs I(0) & PP & with intercept & 13 & $-5.5372^{* * *}$ & $-3.47 ;-2.88 ;-2.58$ \\
\hline$B S I_{F E D, t}$ & $\mathrm{I}(1)$ vs I(0) & ERS & with intercept & 12 & -0.8976 & $-2.58 ;-1.94 ;-1.62$ \\
\hline$B S I_{F E D, t}$ & $\mathrm{I}(0)$ vs I(1) & KPSS & $\mathrm{mu}$ & 13 & $0.4722^{* *}$ & $0.74 ; 0.46 ; 0.35$ \\
\hline$B S I_{F E D, t}$ & $\mathrm{I}(1)$ vs I(0) & ZA & intercept & 12 & $-4.7347^{*}$ & $-5.34 ;-4.8 ;-4.58$ \\
\hline$B S I_{F E D, t}$ & $\mathrm{I}(2)$ vs I(1) & ADF & drift & 1 & $-13.9488^{* * *}$ & $-3.46 ;-2.88 ;-2.57$ \\
\hline
\end{tabular}

N. A. Koçak, "Are CBRT's Monetary Policy Statements Affected by ECB and FED Statements?, Journal of BRSA Banking and Financial Markets, 14, (2), 2020, 205-226 


\begin{tabular}{|c|c|c|c|c|c|c|}
\hline Series & $\begin{array}{l}\text { Null } \\
\text { vs. Alternative } \\
\text { Hypothesis }\end{array}$ & Test name & Test type & $\begin{array}{r}\mathrm{Lag} \\
\text { length }\end{array}$ & $\begin{array}{r}\text { Test } \\
\text { Statistics }\end{array}$ & Critical Values \\
\hline$B S I_{F E D, t}$ & I(2) vs I(1) & PP & with intercept & 13 & $-22.4172^{* * *}$ & $-3.47 ;-2.88 ;-2.58$ \\
\hline$B S I_{F E D, t}$ & $I(2)$ vs I(1) & ERS & with intercept & 11 & -0.8655 & $-2.58 ;-1.94 ;-1.62$ \\
\hline$B S I_{F E D, t}$ & $\mathrm{I}(1)$ vs I(2) & KPSS & $\mathrm{mu}$ & 13 & 0.0579 & $0.74 ; 0.46 ; 0.35$ \\
\hline$B S I_{F E D, t}$ & $I(2)$ vs I(1) & ZA & intercept & 12 & -4.4809 & $-5.34 ;-4.8 ;-4.58$ \\
\hline$C P I_{T R}$ & $\mathrm{I}(1)$ vs I(0) & ADF & drift & 1 & $-2.6608^{*}$ & $-3.46 ;-2.88 ;-2.57$ \\
\hline$C P I_{T R}$ & $I(1)$ vs I(0) & PP & with intercept & 4 & -2.3773 & $-3.47 ;-2.88 ;-2.58$ \\
\hline$C P I_{T R}$ & $\mathrm{I}(1)$ vs I(0) & ERS & with intercept & 1 & $-2.5334^{* *}$ & $-2.58 ;-1.94 ;-1.62$ \\
\hline$C P I_{T R}$ & $I(0)$ vs I(1) & KPSS & $\mathrm{mu}$ & 4 & $1.1963^{* * *}$ & $0.74 ; 0.46 ; 0.35$ \\
\hline$C P I_{T R}$ & $I(1)$ vs I(0) & ZA & intercept & 1 & -4.1409 & $-5.34 ;-4.8 ;-4.58$ \\
\hline$C P I_{T R}$ & $\mathrm{I}(2)$ vs I(1) & $A D F$ & drift & 1 & $-8.8246^{* * *}$ & $-3.46 ;-2.88 ;-2.57$ \\
\hline$C P I_{T R}$ & $I(2)$ vs I(1) & PP & with intercept & 4 & $-9.205^{* * *}$ & $-3.47 ;-2.88 ;-2.58$ \\
\hline$C P I_{T R}$ & I(2) vs I(1) & ERS & with intercept & 1 & $-6.8258^{* * *}$ & $-2.58 ;-1.94 ;-1.62$ \\
\hline$C P I_{T R}$ & $I(1)$ vs I(2) & KPSS & $\mathrm{mu}$ & 4 & 0.0368 & $0.74 ; 0.46 ; 0.35$ \\
\hline$C P I_{T R}$ & $I(2)$ vs I(1) & ZA & intercept & 12 & $-6.3853^{* * *}$ & $-5.34 ;-4.8 ;-4.58$ \\
\hline
\end{tabular}

Note: The column "Critical values" presents the critical values for the levels 1, 5 and 10 pct. respectively.

${ }^{*} ; p<0.1 ;{ }^{* *} ; p<0.05 ;{ }^{* * *} ; p<0.01$

The appropriate lag length is determined for the ARDL specification by the dicrimation of the sample coverage, then the UECM model is estimated by different samples using these appropriate lag lengths minus one due to the differenced variables are used. Three different samples are used, i.e. Full sample, Jan 2008-May 2013 and June 2013-Aug 2020. Table 3 presents the results of the lag length determination by sample coverage. 
Table 3. The lag selection of ARDL model for different samples

\begin{tabular}{|c|c|c|c|c|c|c|c|}
\hline Sample & $B S I_{C B R T, t}$ & $\mathrm{CPI}_{\mathrm{TR}, \mathrm{t}}$ & $\left.B S\right|_{E C B, t}$ & $\left.B S\right|_{F E D, t}$ & Adj. $R^{2}$ & BG $\chi^{2}$ & AIC \\
\hline Full Sample & 1 & 1 & 1 & 1 & 0.494 & $3.59^{* *}$ & 620.29 \\
\hline Full Sample & 1 & 2 & 1 & 1 & 0.494 & 2.43 & 617.36 \\
\hline Full Sample & 1 & 2 & 2 & 1 & 0.503 & 2.7 & 615.73 \\
\hline Full Sample & 1 & 2 & 2 & 2 & 0.502 & 1.51 & 616.9 \\
\hline Full Sample & 1 & 2 & 3 & 1 & 0.502 & 2.43 & 613.82 \\
\hline Full Sample & 1 & 3 & 2 & 1 & 0.502 & $3.35^{* \star}$ & 613.94 \\
\hline Full Sample & 2 & 2 & 2 & 2 & 0.507 & 0.33 & 616.51 \\
\hline Full Sample & 2 & 2 & 2 & 3 & 0.531 & 0.49 & $606.77^{*}$ \\
\hline Full Sample & 2 & 2 & 3 & 2 & 0.506 & 1.02 & 614.54 \\
\hline Full Sample & 2 & 2 & 3 & 3 & $0.533^{*}$ & 1.09 & 606.82 \\
\hline Full Sample & 2 & 3 & 2 & 2 & 0.505 & 0 & 614.8 \\
\hline Full Sample & 2 & 3 & 2 & 3 & 0.53 & 0.07 & 607.85 \\
\hline Full Sample & 2 & 3 & 3 & 3 & 0.532 & 0.47 & 608.21 \\
\hline Full Sample & 3 & 3 & 3 & 3 & 0.529 & 1.04 & 609.94 \\
\hline 2008 Jan-2013 May & 1 & $0^{-}$ & - & 0 & $0.573^{-}$ & 0.65 & 632.5 \\
\hline 2008 Jan-2013 May & 1 & 0 & 1 & 1 & 0.573 & 1.94 & 621.12 \\
\hline 2008 Jan-2013 May & 1 & 0 & 2 & 0 & 0.58 & 0.91 & 627.11 \\
\hline 2008 Jan-2013 May & 1 & 0 & 2 & 1 & 0.578 & 2.31 & 617.29 \\
\hline 2008 Jan-2013 May & 1 & 1 & 1 & 1 & 0.567 & $3.59^{\star \star}$ & 620.29 \\
\hline 2008 Jan-2013 May & 2 & 2 & 2 & 2 & 0.583 & 0.33 & 616.51 \\
\hline 2008 Jan-2013 May & 2 & 3 & 2 & 2 & 0.585 & 0 & 614.8 \\
\hline 2008 Jan-2013 May & 2 & 3 & 2 & 3 & 0.622 & 0.07 & $607.85^{*}$ \\
\hline 2008 Jan-2013 May & 2 & 3 & 3 & 2 & 0.576 & 0.23 & 616 \\
\hline 2008 Jan-2013 May & 2 & 3 & 3 & 3 & 0.615 & 0.47 & 608.21 \\
\hline 2008 Jan-2013 May & 3 & 3 & 3 & 3 & $0.626^{*}$ & 1.04 & 609.94 \\
\hline 2013 Jun-2020 Aug & 1 & 1 & $\overline{1}$ & $\overline{1}$ & 0.436 & $3.59^{-x^{*}-}$ & 620.29 \\
\hline 2013 Jun-2020 Aug & 1 & 2 & 0 & 1 & 0.438 & 2.25 & 615.53 \\
\hline 2013 Jun-2020 Aug & 1 & 2 & 0 & 2 & 0.449 & 0.98 & 616.26 \\
\hline 2013 Jun-2020 Aug & 1 & 2 & 1 & 1 & 0.443 & 2.43 & 617.36 \\
\hline 2013 Jun-2020 Aug & 1 & 2 & 1 & 2 & $0.453^{*}$ & 1.09 & 618.06 \\
\hline 2013 Jun-2020 Aug & 1 & 2 & 1 & 3 & 0.452 & 0.88 & 608.8 \\
\hline 2013 Jun-2020 Aug & 1 & 3 & 1 & 2 & 0.452 & 1.59 & 616.39 \\
\hline 2013 Jun-2020 Aug & 2 & 2 & 0 & 2 & 0.443 & 2.34 & 615.87 \\
\hline 2013 Jun-2020 Aug & 2 & 2 & 1 & 2 & 0.449 & 1.86 & 617.82 \\
\hline 2013 Jun-2020 Aug & 2 & 2 & 1 & 3 & 0.448 & 1.5 & $608.27^{\star}$ \\
\hline 2013 Jun-2020 Aug & 2 & 2 & 2 & 2 & 0.442 & 0.33 & 616.51 \\
\hline 2013 Jun-2020 Aug & 2 & 3 & 1 & 2 & 0.448 & 0.51 & 616.11 \\
\hline 2013 Jun-2020 Aug & 2 & 3 & 2 & 2 & 0.44 & 0 & 614.8 \\
\hline 2013 Jun-2020 Aug & 3 & 3 & 3 & 3 & 0.439 & 1.04 & 609.94 \\
\hline
\end{tabular}

* represents highest Adj. $\mathrm{R}^{2}$ in relevant column, " represents significant auto-correlation problem at \%1 level in LM test column, and * shows minimum AIC value in the relevant column.

Table 3 presents Adj. $R^{2}$, BG test value for auto-correlation, and AIC values for each ARDL estimation with the orders for $B S I_{C B R T}, B S I_{E C B}, B S I_{F E D}$ and $C P I_{T R}$ . Table implies that $\operatorname{ARDL}(2,2,3,3)$ model is found appropriate for the full sample, 
$\operatorname{ARDL}(3,3,3,3)$ model is found appropriate for the sample Jan 2008-May 2013, and $\operatorname{ARDL}(1,2,1,2)$ model is found appropriate for the sample June 2013-August 2020 considering the Adj. $R^{2}$ criterion.

The Bounds tests are performed after proper lag lengths are determined as respectively, $\operatorname{UECM}(1,1,2,2), \operatorname{UECM}(2,2,2,2)$ and $\operatorname{UECM}(0,1,0,1)$ over the full sample, the sample Jan 2008-May 2013, and the sample June 2013-August 2020 using by Eq. (2) to investigate the cointegration relationship among the BSI indicators and $C P I_{T R}$. The F-test and t-test results are presented in Table $4 . \mathrm{k}$ is the number of independent variables in Eq. (2). The critical values are taken from Table $\mathrm{Cl}(\mathrm{V})$ in Pesaran et al. (2001: 300).

Table 4. The Bounds tests results for different sub-samples

\begin{tabular}{|c|c|c|c|c|}
\hline Model & Test type & $\begin{array}{r}\text { Test } \\
\text { statistics }\end{array}$ & $\begin{array}{r}\text { Lower bound } \\
5 \%\end{array}$ & $\begin{array}{r}\text { Upper bound } \\
5 \%\end{array}$ \\
\hline Full Sample & Bounds F-test & $4.708^{*}$ & 3.23 & 4.35 \\
\hline Full Sample & Bounds t-test & $-4.160 *$ & -2.86 & -3.78 \\
\hline 2008 Jan-2013 May & Bounds F-test & 1.239 & 3.23 & 4.35 \\
\hline 2008 Jan-2013 May & Bounds t-test & -1.609 & -2.86 & -3.78 \\
\hline 2013 Jun-2020 Aug & Bounds F-test & $8.282^{*}$ & 3.09 & 4.18 \\
\hline 2013 Jun-2020 Aug & Bounds t-test & $-5.382^{*}$ & -2.86 & -3.78 \\
\hline
\end{tabular}

$\mathrm{k}=3$, Critical bound's values (three regressors, and no trends in the model), Pesaran et al. (2001), p. T.2, Table Cl. iii: Case III. * represents the test statistics higher than upper bound.

The bounds $F$-statistics are found statistically significant for the full and the sample 2013 Jun-2020 Aug since the test statistics are higher than the upper critical values at $5 \%$ level. Moreover, the bounds t-tests are also found significant for those samples. This implies that $B S_{C B R T, t}$ has co-movement with $B S_{E C B, t}, B S_{F E D, t}$ and $C P I_{T R}$ in the long-run for the full sample and after 2013 June.

On the other hand, it is an interesting finding that the long-run relationship does not exist before 2013 June. It can be argued that CBRT sentiments has become closer to ECB and FED statements after FED declared a road map for ending financial stimulus which started after 2009 global financial crisis, and the end of the relationship between IMF and Turkey, which these two events are happened at June 2013.

The long-run and short-run properties of the relationships can be examined since a cointegration relationship is determined between the series. The selected orders 
for ARDL models are already given in Table 3 for the three samples. The estimation results of ARDL models (Eq. (5)) are presented in Table 5 for two samples. Full sample and the sample after 2013 June are used to estimation of ARDL since the cointegration relationships are valid for these two samples.

Table 5. ARDL Estimation Results

\begin{tabular}{|c|c|c|}
\hline & \multicolumn{2}{|c|}{$B S I_{C B R T, t}$} \\
\hline & Full Sample & 2013 Jun-2020 Aug \\
\hline$B S I_{C B R T, t-1}$ & $0.59(0.08)^{* * *}$ & $0.52(0.09)^{* \star *}$ \\
\hline$B S I_{C B R T, t-2}$ & $0.14(0.08)^{*}$ & - \\
\hline$B S I_{C B R T, t-3}$ & - & - \\
\hline $\mathrm{CPI}_{\mathrm{TR}, \mathrm{t}}$ & $0.68(0.53)$ & $0.50(0.68)$ \\
\hline $\mathrm{CPI}_{\mathrm{TR}, \mathrm{t}-1}$ & $0.12(0.81)$ & $-0.10(1.03)$ \\
\hline $\mathrm{CPI}_{\mathrm{TR}, \mathrm{t}-2}$ & $-0.87(0.53)$ & $-0.99(0.67)$ \\
\hline $\mathrm{CPI}_{\mathrm{TR}, \mathrm{t}-3}$ & - & - \\
\hline$B S I_{E C B, t}$ & $0.18(0.18)$ & $0.38(0.29)$ \\
\hline$B S I_{E C B, t-1}$ & $0.10(0.19)$ & $0.37(0.28)$ \\
\hline$\left.B S\right|_{E C B, t-2}$ & $-0.22(0.19)$ & - \\
\hline$\left.B S\right|_{E C B, t-3}$ & $-0.24(0.18)$ & - \\
\hline$B S I_{F E D, t}$ & $-0.31(0.14)^{* *}$ & $-0.47(0.19)^{* *}$ \\
\hline$B S I_{F E D, t-1}$ & $0.42(0.15)^{* * *}$ & $0.65(0.20)^{* * *}$ \\
\hline$B S I_{F E D, t-2}$ & $0.34(0.15)^{* *}$ & $0.30(0.19)$ \\
\hline$B S I_{F E D, t-3}$ & $-0.41(0.13)^{\star \star \star}$ & - \\
\hline Constant & $18.46(12.96)$ & $-37.73(19.26)^{*}$ \\
\hline BG test for autocorrelation & $3.13(2)$ & $3.48(2)$ \\
\hline GQ test for heteroskedasticity & $1.29(61,60)$ & $1.08(34,33)$ \\
\hline $\mathrm{HC}$ test for linearity & $1.16(134)$ & $0.58(76)$ \\
\hline M test for structural change & 1.13 & 1.06 \\
\hline N. obs. & 149 & 87 \\
\hline
\end{tabular}

Standard errors are in parenthesis. ${ }^{* * *} p<0.01 ;{ }^{* *} p<0.05 ;{ }^{*} p<0.01$.

Degrees of freedoms for tests are given in parenthesis near the teststatistics.

The diagnostics are reported at the lower part of Table 5. It can be claimed that the estimated models are robust in terms of the auto-correlation, heteroscedasticity, non-linearity and structural breaks. The estimated coefficients in Table 5 are used to estimate long-run coefficients in Eq. (1). 
Long-run coefficients are calculated using by Eq. (6) and presented in Table 6. Table shows that $C P I_{T R}, B S I_{E C B}$ and $B S I_{F E D}$ have significant effect on $B S I_{C B R T}$ in the long-run. However, this finding is valid for the estimation for the sample 2013 June- 2020 Aug, not for the full sample over which the bounds tests shows the cointegration relationship is significant at \%5 level.

The coefficients of $B S I_{E C B}$ and $B S I_{F E D}$ variables are positive and statistically significant at 5\% level for the sample June 2013 and Aug 2020. The size of $B S I_{E C B}$ and $B S I_{F E D}$ coefficients are equal and over unit size. This finding suggests that $B S I_{C B R T}$ is affected by $B S I_{E C B}$ and $B S I_{F E D}$ with same direction. COnsidering the geographical proximity of Euro area countires and heavity of European countries in foreign trade of Turkey, the closeness of sentiments can be expected. Besides, the closeness of sentiments between CBRT and FED are also expected since FED has great importance in the world monetary balance and Turkish external debt composition is mainly based on US Dollars.

Additionally, the $C P I_{T R}$ 's coefficient is found statistically significant at $10 \%$ level and negative. This finding indicates that the $C P I_{T R}$ and $B S I_{C B R T}$ have an inverse relationship in the long-run. It is expected because CBRT applies inflation targeting and if annual CPI rise, the sentiments of the monetary policy committee turns out to be negative and vice versa.

Table 6. Long-run coefficients

\begin{tabular}{lrr}
\hline Sample & Full Sample & 2013 Jun-2020 Aug \\
\hline$\alpha_{0}$ & $68.252(45.623)$ & $-78.509^{*}(42.359)$ \\
$\mathrm{CPI}_{\mathrm{TR}, \mathrm{t}}$ & $-0.248(0.729)$ & $-1.24^{*}(0.64)$ \\
$\mathrm{BSI}_{\mathrm{ECB}, \mathrm{t}}$ & $-0.671(0.722)$ & $1.549^{* *}(0.634)$ \\
$\mathrm{BSI}_{\mathrm{FED}, \mathrm{t}}$ & $0.162(0.436)$ & $0.999^{* *}(0.424)$ \\
\hline
\end{tabular}

Standard errors are in parenthesis. ${ }^{* * *} p<0.01 ;{ }^{* *} p<0.05 ;{ }^{*} p<0.01$.

UECM model given in Eq. (7) are estimated to examine how $B S I_{E C B}, B S I_{F E D}$ and $C P I_{T R}$ affect the $B S I_{C B R T}$ in the short-run for three sample coverage. Estimation of UECM for the sample before 2013 June is a valid option for BSI variables if there is no cointegration relationship among them. The estimation results are given in Table 7. The diagnostics are also reported at the lower part of Table 7. It can be claimed that the estimated models are robust in terms of the auto-correlation, heteroscedasticity, non-linearity and structural breaks. 


\begin{tabular}{|c|c|c|c|}
\hline & \multicolumn{3}{|c|}{$\Delta \mathrm{BSI}_{\mathrm{CBRT}, \mathrm{t}}$} \\
\hline & Full Sample & 2008 Jan-2013 May & 2013 Jun-2020 Aug \\
\hline $\mathrm{ECT}_{\mathrm{t}-1}$ & $-0.27(0.06)^{* \star \star}$ & $-0.17(0.07)^{* *}$ & $-0.48(0.08)^{* * *}$ \\
\hline $\boldsymbol{\Delta} \mathrm{BSI}_{\mathrm{CBRT}, \mathrm{t}-1}$ & $-0.14(0.08)^{*}$ & $-0.18(0.12)$ & \\
\hline$\Delta \mathrm{BSI}_{\mathrm{CBRT}, \mathrm{t}-2}$ & - & $-0.22(0.13)^{*}$ & \\
\hline$\Delta \mathrm{CPI}_{\mathrm{TR}, \mathrm{t}}$ & $0.68(0.50)$ & $-0.64(0.89)$ & $0.50(0.61)$ \\
\hline$\Delta \mathrm{CPI}_{\mathrm{TR}, \mathrm{t}-1}$ & $0.87(0.51)^{*}$ & $1.84(0.90)^{* *}$ & $0.99(0.64)$ \\
\hline$\Delta \mathrm{CPI}_{\mathrm{TR}, \mathrm{t}-2}$ & - & $1.12(0.93)$ & \\
\hline$\Delta \mathrm{BSI}_{\mathrm{ECB}, \mathrm{t}}$ & $0.18(0.17)$ & $0.30(0.22)$ & $0.38(0.24)$ \\
\hline $\boldsymbol{\Delta} \mathrm{BSI}_{\mathrm{ECB}, \mathrm{t}-1}$ & $0.46(0.18)^{\star \star}$ & $0.41(0.24)^{*}$ & \\
\hline$\Delta \mathrm{BSI}_{\mathrm{ECB}, \mathrm{B}, \mathrm{t}-2}$ & $0.24(0.17)$ & $0.03(0.22)$ & - \\
\hline$\Delta \mathrm{BSI}_{\mathrm{FED}, \mathrm{t}, \mathrm{t}}$ & $-0.31(0.13)^{* *}$ & $-0.16(0.17)$ & $-0.47(0.18)^{* * *}$ \\
\hline$\Delta \mathrm{BSI}_{\mathrm{FED}, \mathrm{t}-1}$ & $0.07(0.15)$ & $-0.06(0.18)$ & $-0.30(0.18)^{*}$ \\
\hline$\Delta \mathrm{BSI}_{\mathrm{FED}, \mathrm{t}-\mathrm{t}-2}$ & $0.41(0.13)^{* * *}$ & $0.39(0.18)^{* *}$ & \\
\hline Constant & $18.46(4.24)^{\star * \star}$ & $29.77(12.91)^{* *}$ & $-37.73(6.50)^{* * *}$ \\
\hline BG test for autocorrelation & $2.97(2)$ & $0.29(2)$ & $3.18(2)$ \\
\hline GQ test for heteroskedasticity & $1.33(64,63)$ & $0.64(18,18)$ & $1.16(37,36)$ \\
\hline $\mathrm{HC}$ test for linearity & $1.8(137)$ & $0.9(48)$ & $0.59(79)$ \\
\hline M test for structural change & 1.12 & 1.22 & 1.09 \\
\hline Num. obs. & 149 & 62 & 87 \\
\hline
\end{tabular}

Standard errors are in parenthesis. ${ }^{* * *} p<0.01 ;{ }^{* *} p<0.05 ;{ }^{*} p<0.01$.

Degrees of freedoms for tests are given in parenthesis near the test statistics.

The coefficients of the error correction variable $\left(E C T_{t-1}\right)$ are negative and between 0 and -1 . The fact that the coefficient is negative and less than one means that the system is stabilized by fluctuating, and this fluctuation will gradually decrease each time and return to balance in the long-run. As a result, it is negative and statistically significant as expected.

The effect of $B S I_{E C B}$ on $B S I_{C B R T}$ is positive and noticeably for the full sample and the sample before 2013 June, however the effect has become weak after 2013 June. The effect of $B S I_{F E D}$ on $B S I_{C B R T}$ has mixed properties. For the full sample, it has negative effect at $t$, but it has positive effect at $t-2$. So, the whole effect is become neutral. For the sample 2008 Jan - 2013 June, it has positive effect on $B S I_{C B R T}$. On the other hand, it has sronge negative effect on $B S I_{C B R T}$ after the period 2013 June. Besides, the effect of $C P I_{T R}$ on $B S I_{C B R T}$ is positive and noticeably for the full sample and the sample before 2013 June, however the effect has become weak after 2013 June. 
To sum up, it may be concluded that CBRT sentiments are positively affected by the ECB and FED sentiments in the long-run, and only negatively affected by the FED sentiments in the short-run The common movement of statements in the long-run is sensible because monetary policies are also related in the long-run. On the other hand, the management of capital movements and tightening measures for price stability taken by CBRT may cause an inverse relationship with the FED in the short-run.

\section{Conclusion}

The monetary policy statements are important communication tools for central banks. However, there are very few studies in the literature regarding the examination of the relationships among the central banks' statements. Therefore, the main concern of this paper is to investigate how the CBRT sentiments are affected by the ECB and the FED sentiments. The analysis covers the period between January 2008-August 2020. Two sub-samples, i.e. before and after 2013 June, are analysed in addition to the full sample. In this paper, the monthly sentiment indicators are calculated from the statements of CBRT, ECB, and FED. These indicators show the balance between the positivity and the negativity scores of the statements. Several unit root test and the Bounds test are performed to investigate the individual and group time series characteristics. Then, ARDL and UECM models are estimated to examine the short and long-run relationship between the sentiments of CBRT, ECB, and FED statements.

The bounds test results suggest that the balance sentiment indicators of CBRT, $E C B$, and FED have statistically significant cointegration relationship for the full sample and after June 2013. This implies that sentiments of CBRT statements are in line with ECB and FED statements' after June 2013 when the relationship between IMF and Turkey is officially ended. Long-run and short-run dynamics shows that ECB statements have strong effect on the CBRT statements in the long run but weak in the short-run. On the other hand, FED statements have strong effect on the CBRT statements in the long and short-run. The sign of the effect is positive in the long-run however it is negative in the short-run.

It should be noted that the "monetary expansion" policies and "macro-prudential" measures implemented after the 2008 crisis had a significant impact on the economy. In particular, the macro-prudential measures such as the ROM mechanism followed by the CBRT was used to reduce the effects of the FED and ECB's monetary expansion policies. 
Several implications can be derived from the findings. The estimated long-run elasticity of ECB indicates that the CBRT statements are in line with the ECB statements in the long-run. This behavior can be explained by the geographic proximity and high-level foreign trade partnership. The long-run relationship between CBRT and ECB statements is positive after 2013 June when this date coincides with two events. June 2013 is the date when CBRT made a change in monetary policy due to the FED outlined an end to its stimulus to the USA economy, and announced an official end the relationship between IMF and Turkey.

By contrast, the FED statements inversely affect the CBRT statements in the short-run. The negative relationship between them can be explained by the increase in the needs for the short-term funds in Turkey due to the FED continuously hikes the Federal fund rate after the stimulus period. The issues that can be addressed in the future can be given as including all communication tools of CBRT in the analysis which processed through an expanded-Taylor rule model. 


\section{References}

1. Armelius, H., Bertsch, C., Hull, I., \& Zhang, X. (2020). Spread the Word: International spillovers from central bank communication. Journal of International Money and Finance, 103, 102116.

2. Bårdsen, G. (1989). Estimation of long run coefficients in error correction models. Oxford Bulletin of Economics and Statistics, 51(3), 345-350.

3. Bec, F., Salem, M. B., \& Collard, F. (2002). Asymmetries in monetary policy reaction function: evidence for US French and German central banks. Studies in Nonlinear Dynamics \& Econometrics, 6(2).

4. Berger, H., De Haan, J., \& Sturm, J. E. (2011). Does money matter in the ECB strategy? New evidence based on ECB communication. International Journal of Finance \& Economics, 16(1), 16-31.

5. Bernanke, B. S., \& Reinhart, V. R. (2004). Conducting monetary policy at very low short-term interest rates. American Economic Review, 94(2), 85-90.

6. Bholat, D. (2015). Big data and central banks. Big Data \& Society, 2(1).

7. Breusch, T. S. (1978). Testing for autocorrelation in dynamic linear models. Australian Economic Papers, 17(31), 334-355.

8. Coenen, G., Ehrmann, M., Gaballo, G., Hoffmann, P., Nakov, A., Nardelli, S., ... \& Strasser, G. (2017). Communication of Monetary Policy in Unconventional Times. ECB Working Paper. No. 2080.

9. Dickey, D. A., \& Fuller, W. A. (1981). Likelihood ratio statistics for autoregressive time series with a unit root. Econometrica: journal of the Econometric Society, 1057-1072.

10. Elliott, G., Rothenberg, T. J., \& James, H. (1996). Stock, 1996, “Efficient tests for an autoregressive unit root,". Econometrica, 64(4), 813-836.

11. Engle, R. F., \& Granger, C. W. (1987). Co-integration and error correction: representation, estimation, and testing. Econometrica: journal of the Econometric Society, 251-276.

12. Goldfeld, S. M., \& Quandt, R. E. (1965). Some tests for homoscedasticity. Journal of the American statistical Association, 60(310), 539-547. 
13. Gujarati, D. N. (2009). Basic econometrics. Tata McGraw-Hill Education.

14. Hansen, S., \& McMahon, M. (2016). Shocking language: Understanding the macroeconomic effects of central bank communication. Journal of International Economics, 99, S114-S133.

15. Hansen, S., McMahon, M., \& Prat, A. (2018). Transparency and deliberation within the FOMC: a computational linguistics approach. The Quarterly Journal of Economics, 133(2), 801-870.

16. Harvey, A. C., \& Collier, P. (1977). Testing for functional misspecification in regression analysis. Journal of Econometrics, 6(1), 103-119.

17. Henry, E. (2008). Are investors influenced by how earnings press releases are written?. The Journal of Business Communication (1973), 45(4), 363-407.

18. Hu, M., \& Liu, B. (2004, August). Mining and summarizing customer reviews. In Proceedings of the tenth ACM SIGKDD international conference on Knowledge discovery and data mining (pp. 168-177).

19. Iglesias, J., Ortiz, A., \& Rodrigo, T. (2017). How do the emerging markets central bank talk? A big data approach to the Central Bank of Turkey (Vol. 24). BBVA Working Paper.

20. Johansen, S., \& Juselius, K. (1990). Maximum likelihood estimation and inference on cointegration-with appucations to the demand for money. Oxford Bulletin of Economics and statistics, 52(2), 169-210.

21. Johansen, S. (1988). Statistical analysis of cointegration vectors. Journal of economic dynamics and control, 12(2-3), 231-254.

22. Kahveci, E., \& Odabaş, A. (2016). Central banks' communication strategy and content analysis of monetary policy statements: The case of Fed, ECB and CBRT. Procedia-Social and Behavioral Sciences, 235, 618-629.

23. Kwiatkowski, D., Phillips, P. C., Schmidt, P., \& Shin, Y. (1992). Testing the null hypothesis of stationarity against the alternative of a unit root. Journal of econometrics, 54(1-3), 159-178.

24. Loughran, T., \& McDonald, B. (2011). When is a liability not a liability? Textual analysis, dictionaries, and $10 \mathrm{Ks}$. The Journal of Finance, 66(1), 35-65. 
25. Mohammad, S. M., \& Turney, P. D. (2013). Crowdsourcing a word-emotion association lexicon. Computational Intelligence, 29(3), 436-465.

26. Pesaran, M. H., Shin, Y., \& Smith, R. J. (2001). Bounds testing approaches to the analysis of level relationships. Journal of applied econometrics, 16(3), 289-326.

27. Phillips, P. C., \& Perron, P. (1988). Testing for a unit root in time series regression. Biometrika, 75(2), 335-346.

28. Rinker, T. W. (2016). sentimentr: Calculate text polarity sentiment. University at Buffalo/SUNY, Buffalo, New York. version 0.5, 3.

29. Siklos, P. L., \& Wohar, M. E. (1997). Convergence in interest rates and inflation rates across countries and over time. Review of International Economics, 5(1), 129-141.

30. Stegmann, J. (2019). Federal Open Market Committee communication: a text mining analysis, unpublished Bachelor thesis.

31. Throop, A. W. (1994). International financial market integration and linkages of national interest rates. Economic Review-Federal Reserve Bank of San Francisco, (3), 3.

32. Young, L., \& Soroka, S. (2012). Affective news: The automated coding of sentiment in political texts. Political Communication, 29(2), 205-231.

33. Zeileis, A. (2006). Implementing a class of structural change tests: An econometric computing approach. Computational Statistics \& Data Analysis, 50(11), 2987-3008.

34. Zivot, E., \& Andrews, D. W. K. (2002). Further evidence on the great crash, the oil-price shock, and the unit-root hypothesis. Journal of business \& economic statistics, 20(1), 25-44. 